\title{
An offshore transgressive-regressive mudstone-dominated succession from the Sinemurian of Skåne, Sweden
}

\author{
Nils Frandsen and Finn Surlyk
}

A Sinemurian mudstone-dominated succession was exposed until recently in the Gantofta quarry in Skåne, southern Sweden. The deposits are placed in the Döshult and Pankarp Members of the Sinemurian-Aalenian Rya Formation. Similar facies of the same age are widespread in the Danish Basin where they constitute the F-Ib unit (F-I member) of the Fjerritslev Formation. The Gantofta succession thus represents the easternmost extension of the environment characteristic of the Fjerritslev Formation and is essentially the only locality where it has been possible to study the facies of this formation in outcrop. Sedimentation seems to have taken place under relatively quiet tectonic conditions except for the possible fault-control of the basin margin. The lower part of the Gantofta section is of Early and early Late Sinemurian age. It represents the upper part of the Döshult Member and consists of muddy, lower shoreface sandstones, abruptly overlain by dark, bioturbated, fossiliferous mudstones with thin storm siltstones and sandstones. They are overlain by the Upper Sinemurian Pankarp Member which comprises red-brown, restricted marine calcareous mudstones with an upwards increasing number of storm siltstones and sandstones reflecting general shallowing and shoreline progradation.

The succession spans the greater part of two simple sequences with a distal sequence boundary located at the boundary between the Döshult Member and the Pankarp Member. The exposed part of the lower sequence includes a thick transgressive systems tract and a very thin highstand systems tract. The upper sequence is represented by an undifferentiated transgressive and highstand systems tract. An Early Sinemurian sea-level rise, a late Early Sinemurian highstand, an early Late Sinemurian fall and a Late Sinemurian minor rise and a major fall are recognised. Nearby boreholes show evidence for an end-Sinemurian - Early Pliensbachian major rise. This evolution corresponds well with trends recorded in the subsurface Fjerritslev Formation of the Danish Basin.

Comparison with published European and British Jurassic sea-level curves show similar overall trends, but exhibit differences in the precise ages of sequence boundaries and maximum flooding surfaces. This may reflect poor biostratigraphical resolution of the Gantofta section, differences in sequence stratigraphic interpretation, real differences in the age of sequence stratigraphic key surfaces, or the basin marginal position of Gantofta in the Fennoscandian Border Zone.

Keywords: Skåne, southern Sweden, Lower Jurassic, Sinemurian, facies analysis, sequence stratigraphy, sedimentary environments, sea-level change

N.F., DONG, Agern Allé 24-26, DK-2970 Hørsholm, Denmark. E-mail: nfr@dong.dk

F.S., Geological Institute, University of Copenhagen, Geocenter Copenhagen, Øster Voldgade 10, DK-1350 Copenhagen K, Denmark. 
Jurassic sedimentary rocks occur in great thicknesses in the subsurface of Denmark and southern Sweden (Michelsen 1978; Norling et al. 1983; Nielsen 2003, this volume). They are, however, only exposed in a few relatively small outcrops on Bornholm in the Baltic Sea, and in Skåne, southern Sweden, in the Fennoscandian Border Zone (Fig. 1; Sellwood 1972; Rolle et al. 1979; Gravesen et al. 1982; Norling et al. 1983; Surlyk \& NoeNygaard 1986; Ahlberg et al. 2003, this volume). This intensely block-faulted zone forms the north-eastern boundary of the Danish Basin. Detailed facies, biostratigraphic and sequence stratigraphic studies of exposed units are thus of outstanding importance in obtaining a more detailed picture of the sedimentary environments prevailing during Jurassic time in southern Scandinavia.

The aims of the present paper are to interpret the facies and sequence stratigraphy of the Sinemurian offshore marine deposits exposed in the Gantofta quarry in Skåne, southern Sweden, to place the succession in its regional context, and to compare the derived sealevel curve with the sea-level curves of Haq et al. (1988), Hallam (1988) and Hesselbo \& Jenkyns (1998).

\section{Geological setting and stratigraphy}

Gantofta is located close to the NW-SE-trending western margin of the Fennoscandian Border Zone (Fig. 1). The margin is characterised by a major faulted flexure formed by Late Cretaceous - Palaeogene tectonic inversion which marks the transition to the major depocentre of the Danish Basin to the south-west (Norling 1981, fig. 37).

The locality is a small clay pit $(150 \times 100 \mathrm{~m})$ which was abandoned some years ago and the section is thus no longer easily accessible. The ammonites from the succession were described by Reyment (1969a, b), the foraminifera by Norling (1972), the palynology by Lund (1977), the ostracodes by Sivhed $(1977,1980,1981)$ and the sedimentary facies and environments by Frandsen (1977), Rolle et al. (1979) and Pieńkowski (1991a, b). The succession is $70 \mathrm{~m}$ thick and consists of sandstones and mudstones of the Lower - lower Upper Sinemurian Döshult Member and the Upper Sinemurian Pankarp Member, which constitute the two lower members of the Sinemurian-Aalenian Rya Formation (Sivhed 1984; Ahlberg et al. 2003, this volume). The whole succession is tilted, and the strata strike $140^{\circ}$ and $\operatorname{dip} 30^{\circ} \mathrm{SW}$ (Fig. 2).

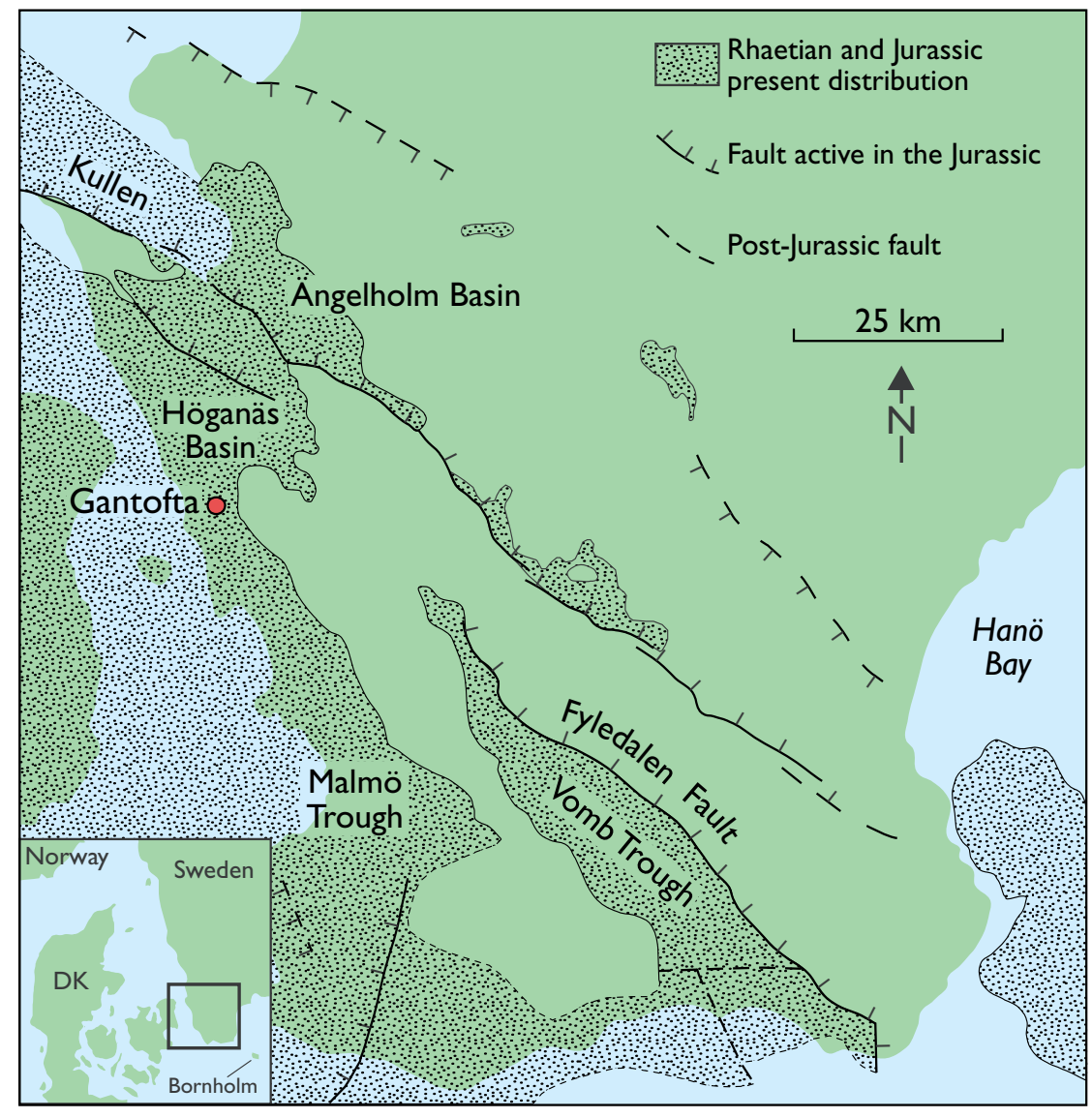

Fig. 1. Map showing the location of Gantofta in the Fennoscandian Border Zone of southern Skåne. Important Jurassic structural features are indicated; note that Jurassic normal faults were subsequently inverted in the Late Cretaceous - Palaeogene. Based on Norling \& Bergström (1987).

DK, Denmark. 
Fig. 2. Geological map and section (A-B) of the Gantofta area. Modified from Sivhed (1981).
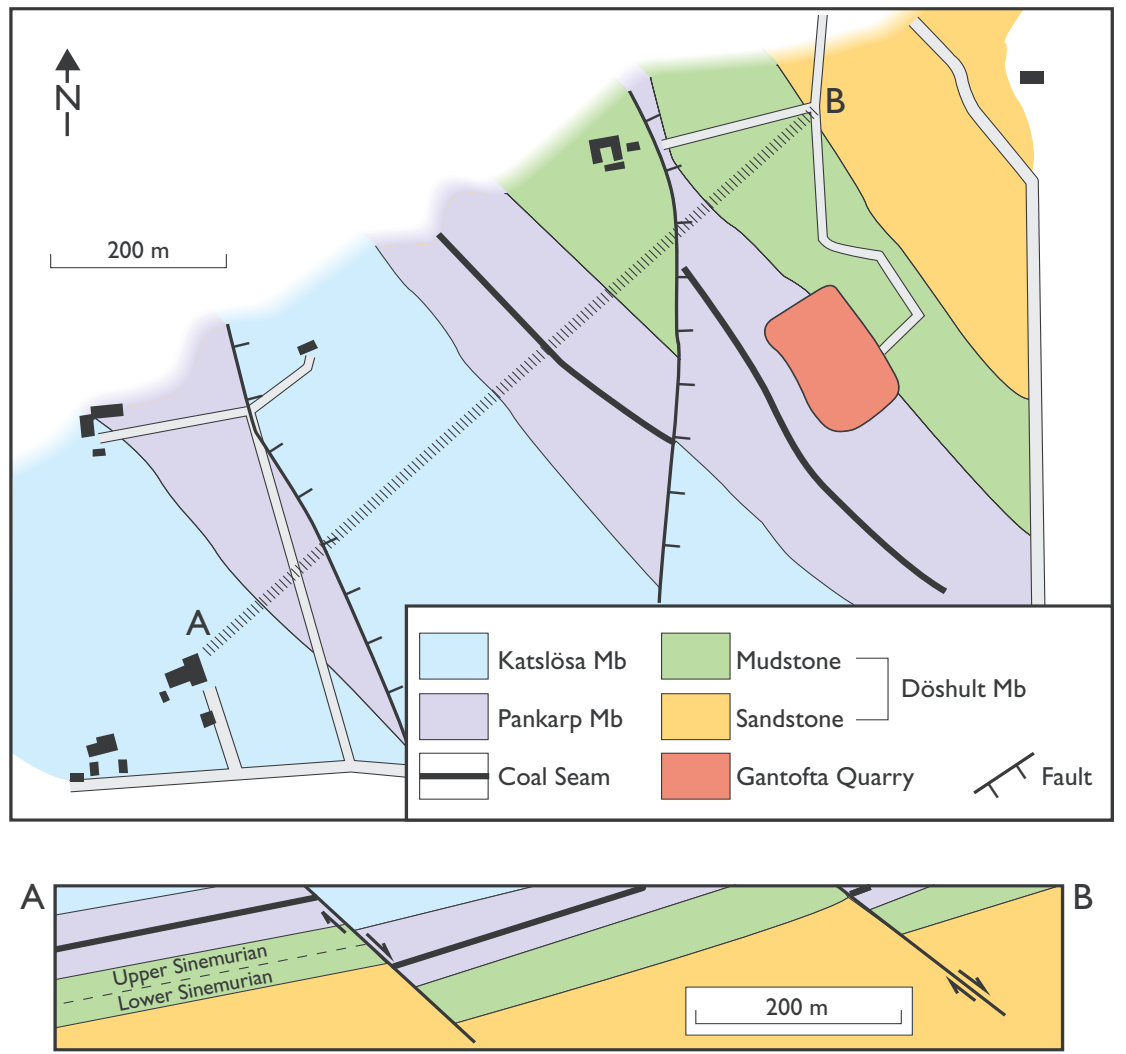

A foraminifer fauna from the middle part of the Döshult Member at the base of the exposure indicates an Early Sinemurian age (Norling 1972). An ammonite fauna including Asteroceras obtusum (Sowerby) and Promicroceras planicostatum (Sowerby) from a level $2 \mathrm{~m}$ below the base of the overlying Pankarp Member is of early Late Sinemurian obtusum Chronozone, planicostatum Subzone age (Reyment 1969a). K. Hoffman (in: Bölau 1959) reported the occurrence of the birchi Subzone (top of the turneri Chronozone) immediately below the base of the Pankarp Member. The ostracode faunas of the Döshult Member indicate a latest Early Sinemurian to Late Sinemurian age (Sivhed 1977). Norling (1972) suggested that the succession spans the time interval of the semicostatum to obtusum Chronozones. A new find of the ammonite Euagassiceras cf. lundgreni Reyment in the basal muddy sandstone of the section suggests a mid Early Sinemurian semicostatum Chronozone age for this level (probably resupinatum Subzone). This is in agreement with Bölau (1973).

Correlative strata are widely distributed in the Danish Basin where they form the F-Ib unit (F-I member) of the thickly developed, uniform mudstone package of the Fjerritslev Formation (Michelsen 1975, 1978, 1989; Pedersen 1985, 1986; Michelsen et al. 2003, this volume;
Nielsen 2003, this volume). The succession of the Gantofta quarry consists of similar facies and thus essentially represents the only locality where it has been possible to study the characteristic facies of the otherwise deeply buried Fjerritslev Formation in outcrop.

\section{Sedimentology}

A detailed sedimentological log of the succession was measured in 1975-1976 by Frandsen (1977). Special emphasis was placed on recording primary sedimentary structures, body and trace fossils, and details of concretions and other diagenetic features were also noted. Five sedimentary facies are recognised and are described below followed by an interpretation of the depositional processes and environments.

\section{Sedimentary facies}

\section{Muddy sandstone (facies 1)}

This facies consists of fine- to very fine-grained quartz sandstone with a mud-rich matrix. It is only known 

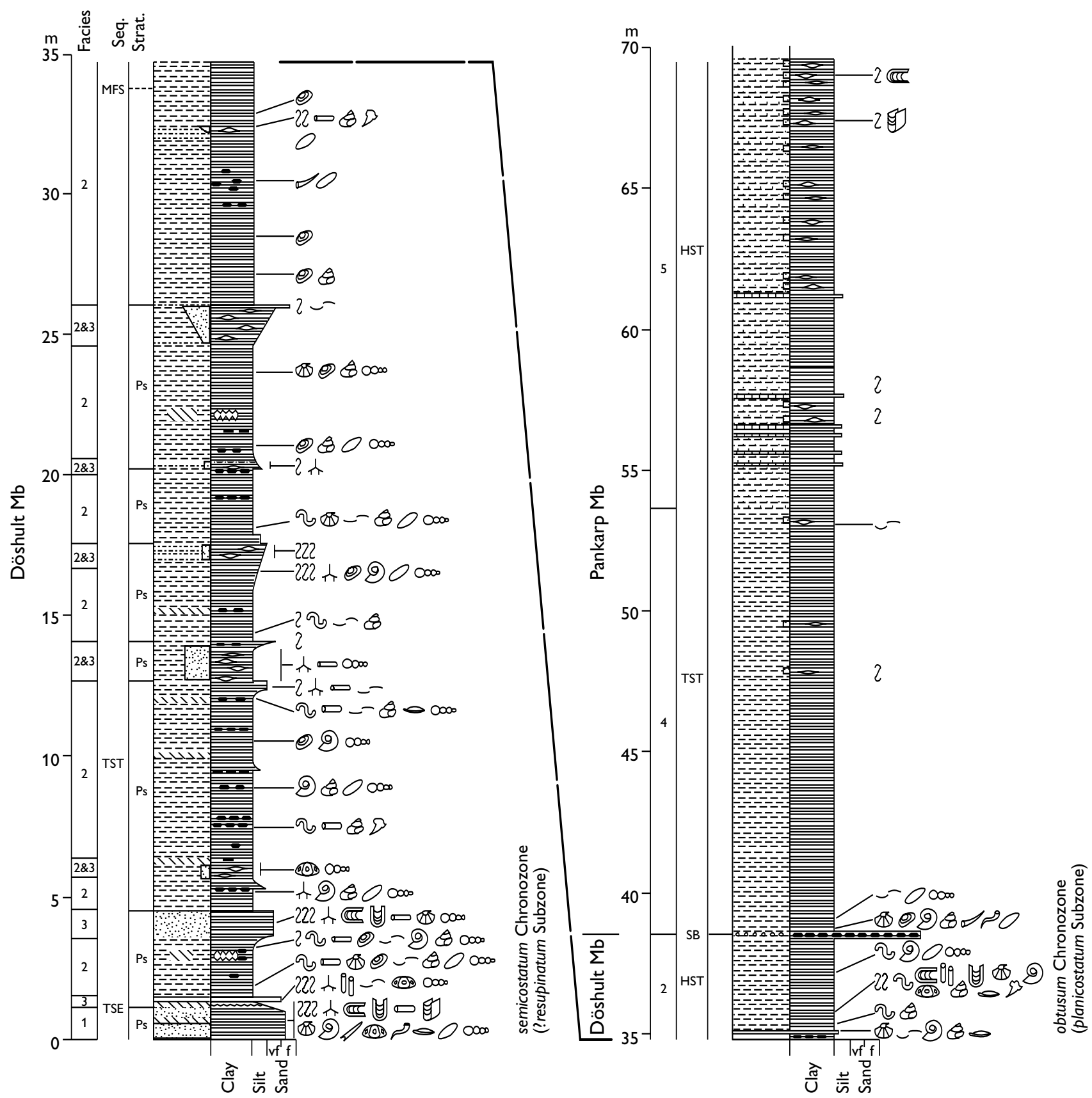

\begin{tabular}{|c|c|c|}
\hline Lithology & \multicolumn{2}{|c|}{ Trace fossils } \\
\hline$E=-9 u d s t o n e$ & 卉 & Chondrites isp. \\
\hline Calcareous mudstone & 匹 & Rhizocorallium isp. \\
\hline Silty and sandy mudstone & $\theta$ & Diplocraterion isp. \\
\hline Silt- and sandstone & $\sigma$ & Planolites isp. \\
\hline NV Carbonate cemented & of & Skolithos isp. \\
\hline$\leadsto$ Conglomerate & 囚 & Pyritic tube \\
\hline Structures & 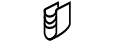 & Teichichnus isp. \\
\hline Parallel lamination & 222222 & $\begin{array}{l}\text { Bioturbation } \\
\text { increasing density }\end{array}$ \\
\hline \multicolumn{3}{|l|}{$\begin{array}{l}\text { Parallel lamination with } \\
\text { siltstone lenses }\end{array}$} \\
\hline$\widetilde{\ldots}$ Cone-in-cone structures & & \\
\hline - Clay ironstone concretions & & \\
\hline
\end{tabular}

\section{Body fossils}

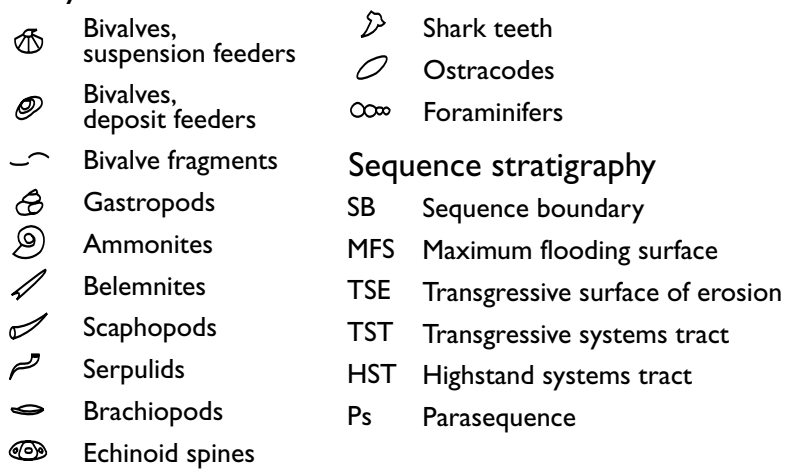

Fig. 3. Sedimentological section showing the biostratigraphy, chronostratigraphy and sequence stratigraphy of the Sinemurian succession at Gantofta. 
from the base of the section (Fig. 3). Shelly coquinas with quartz granules occur at some levels. The colour varies from light grey to dark grey. The sandstone is almost totally bioturbated and the original structures are commonly difficult to recognise. However, fine biogenic lamination caused by high densities of the trace fossil Teichichnus isp. is a characteristic feature of the facies. Siderite is the dominant cement, whereas the most indurated beds have a calcitic cement.

The trace fossils include Teichichnus isp., Diplocraterion isp., Rhizocorallium isp., Chondrites isp., Planolites isp. and Zapfella isp.; the last of these occurs as elongate borings in shells of the bivalve Liogryphaea arcuata.

The facies contains a fully marine fauna of body fossils which occur in rather high densities. Frandsen (1977) compiled a list of the fauna and documented the presence of species described from other localities by Troedsson (1951). A taxonomic revision has not been attempted. The fauna includes the bivalves Liogryphaea arcuata, Chlamys textoria, Chlamys interpunctata, Entolium sp., and Oxytoma sinemuriensis, the ammonite Euagassiceras cf. lundgreni Reyment, and indeterminate belemnites, echinoids, serpulids, ostracodes and nodosariid foraminifera. Coalified wood occurs as scattered pieces up to $6 \mathrm{~cm}$ long. The preservation of the shells is quite variable. Some are well-preserved and unworn, while others occur in coquinas and have clearly undergone some transport and destruction.

The combination of marine body and trace fossils, intense bioturbation, shelly coquinas and a sand-dominated grain size indicates deposition under well-oxygenated marine conditions with normal salinity and relatively low sedimentation rates, periodically interrupted by higher energy events resulting in erosion, reworking and transport of shells. The taphonomic conditions suggest that the fauna can be considered a neighbourhood assemblage representing a fauna which lived in the area and which underwent only limited transport. The muddy nature of the sandstone suggests that the original facies was a sand-dominated, possibly flaserbedded heterolith, but the very high degree of bioturbation does not allow a detailed process interpretation.

\section{Dark grey mudstone (facies 2)}

The mudstone of this facies characterises the bulk of the exposed part of the Döshult Member (Fig. 3). It has a high content of silt and fine sand. Silt and clay are roughly equally abundant, and the clay is dominated by kaolinite with some illite and chlorite. Coaly detritus, muscovite, very small shells and shell fragments, and framboidal pyrite nodules $(0.1-0.3 \mathrm{~mm}$ in diameter) are characteristic constituents. A few intervals, up to $1 \mathrm{~m}$ thick, have a relatively higher content of sand and can be classified as muddy sandstones.

The mudstone is laminated with light coloured laminae of coarse silt, $1 \mathrm{~mm}$ thick. Clay ironstone is a characteristic component and occurs as bedding-parallel siderite impregnated layers, $5 \mathrm{~cm}$ thick, with ellipsoidal concretions, $5-20 \mathrm{~cm}$ long. Thin conglomerate beds consisting of reworked clay-ironstone concretions are found at the $35.05 \mathrm{~m}$ and $38 \mathrm{~m}$ levels (Fig. 3). Carbonate concretions with cone-in-cone structures occur at several levels.

The facies is strongly bioturbated, especially in the sandier portions, but several recognisable trace fossils were noted, including Diplocraterion isp., Skolithos isp., Rhizocorallium isp. (which has only been recorded from the clay-ironstone conglomerate) and Chondrites isp. Pyritic tubes, $0.2-1.0 \mathrm{~mm}$ in diameter, probably representing burrows of small deposit feeders, and ?Planolites isp. occur throughout.

This facies and the laminated siltstone-sandstone facies (facies 3) contain a rich shelly fauna. The two facies and their faunas are closely related and their faunas are described together here. The carbonate shells have undergone dissolution and are mainly poorly preserved, but wear due to transport appears to be negligible. Liogryphaea arcuata is relatively rare and the specimens are smaller than those of facies 1 . Two species of Chlamys and minute specimens of Oxytoma sinemuriensis have been found. A major difference in faunal composition compared to facies 1 is the abundance of deposit-feeding bivalves of the Nuculanacea (Nuculana, Palaeoneilo, Rollieria, Leda) and Nuculacea (Nucula). Bivalves belonging to Cardinia, Astarte, Homomya and Pleuromya or related genera also occur, but the determinations are uncertain. Small, high-spired gastropods representing a number of different genera are very common. Poorly preserved scaphopods, brachiopods, ammonites and rare shark teeth occur at several levels.

The fine-grained muds were deposited from suspension in an offshore open marine environment. The content of silt and sand probably represents material transported to the area during storms. Bioturbation then resulted in mixing of the fine and coarser fractions, and destruction of primary current-produced structures. The high density and diversity of body and trace fossils show that the water was of normal salinity and well- 
oxygenated. The abundance of deposit feeders is a common characteristic of fine-grained, nutrient-rich sediments, whereas the abundant small-sized gastropods suggest the presence of a marine vegetation.

The clay ironstone layers were formed under conditions of negative Eh, low concentration of sulphide ions, high activity of ferrous ions, and the presence of bicarbonate ions. Following Sellwood (1971) it is suggested that iron was transported to the marine environment and deposited as insoluble ferrioxide which was adsorbed on clay minerals. The siderite nodules contain undeformed trace fossils and the mudstone shows compaction features around the nodules which were thus formed after burrowing but before compaction.

\section{Laminated siltstone-sandstone (facies 3)}

This facies varies in grain size from coarse silt to fine sand, but grains up to granule size occur set in a muddy matrix. It forms beds up to 1-2 $\mathrm{m}$ thick and is commonly interbedded with facies 2 . More than $95 \%$ of the grains consist of quartz. Other components are plagioclase, muscovite and coaly grains. Nodules of framboidal pyrite with a diameter of $0.1 \mathrm{~mm}$ occur locally. The cement consists mainly of calcite.

The facies is parallel laminated, but structureless intervals are also observed and primary structures are commonly obliterated by bioturbation. Laminae are normally 1-2 mm thick, and may be graded from fine sand to coarse silt. Thin laminae of shell hash occur locally.

The facies is strongly bioturbated. Recognizable trace fossils include rare Skolithos isp., Chondrites isp., Rhizocorallium isp. with protrusive spreiten, and ?Pygospioides isp. which is very similar to Chondrites, but more closely resembles Pygospioides isp. as described from the Hettangian of Niedersachsen by Häntzschel \& Reineck (1968). ?Planolites isp. traces occur throughout the facies. Body fossils are described under facies 2 (see above).

The coarse siltstones and sandstones of this facies probably represent distal offshore storm deposits (Pedersen 1985), but the pervasive bioturbation precludes an unequivocal interpretation.

\section{Variegated mudstone (facies 4)}

This facies and facies 5 characterise the Pankarp Member in the upper part of the section (Fig. 3). It differs from facies 2 in the red-brown colour and a finer grain size dominated by clay and silt. Some levels are light-grey with a greenish tinge. The colour difference from facies 2 is associated with a greater content of iron; the red variety is richer in ferric and poorer in ferrous compounds than the greenish variety. The facies shows some lamination and upwards in the succession thin lenticular silt ripples start to appear.

A few indeterminate bivalves and some pyrite-impregnated nodosariid foraminifers have been found. The facies was deposited under low energy conditions, probably in a marginal marine environment as inferred from the impoverished fauna and the scarcity of bioturbation compared to facies 2 and 3 .

\section{Calcareous siltstone and mudstone (facies 5)}

The facies consists of intimately interbedded, soft, variegated claystone and siltstone of the same type as facies 4 , and harder light grey coarse siltstone and very fine sandstone. Up to $60-70 \%$ of the sediment consists of calcite while quartz, clay and some muscovite constitute the remaining part. The calcite occurs as recrystallized cement and grains of uncertain origin. Comminuted coaly fragments occur throughout.

The facies shows an almost varve-like grading with 5-17 $\mathrm{mm}$ thick beds. The graded beds pass from light grey, calcite-rich clay into red clay, poor in calcite. The lower boundaries of the graded beds are sharp and the tops are flat or gently undulating. Some of the thicker, coarser-grained beds show parallel lamination passing into low-amplitude hummocky cross-stratification. These beds also display load structures, groove casts, flatlying folds and wrinkle marks on their upper surfaces. The wrinkle marks are very similar to the Kinneya ripples of Reineck \& Singh (1980).

Trace fossils are scarce, typically represented by scattered 3-4 mm wide subhorizontal burrows, whereas Teichichnus isp. and subhorizontal Rhizocorallium isp. with protrusive spreiten are found in the upper coarsergrained part of the succession. Body fossils are only represented by scattered shell fragments.

The fine grain size and the scarcity of trace and body fossils suggest deposition under very low energy conditions in a marginal or high stress marine environment. The graded beds probably represent deposition from storm-induced suspension clouds (Pedersen 1985). The upwards increase in grain size and in the frequency of beds displaying parallel lamination and hummocky cross-stratification indicate increasingly storm-influenced 
deposition. The sum of characters thus indicates deposition under low energy conditions interrupted by sudden influxes of storm-derived sediments. The environment may have been distant offshore or more likely a relatively protected shallow marine area where the available grain sizes were very fine and where the effects of storm events were relatively subtle. The red coloration and the presence of Kinneya-type wrinkle marks lend some credence to the latter hypothesis. The wrinkle marks may have been caused by a strong wind blowing over a cohesive, fine-grained sediment covered by only a thin veneer of water, possibly with a microbial mat growing on the sea floor under environmentally stressed conditions (Reineck \& Singh 1980). They are thus indicative of near emergent conditions. As indicated on the geological map (Fig. 2), a coal seam is situated slightly above the studied section. This also suggests that facies 5 was deposited in a marginal to non-marine environment.

\section{Depositional environment}

Facies 1-5 form a regular vertical succession with facies 1 at the base and facies 5 at the top, and interbedding only occurs between facies 2 and 3. The section thus includes a basal muddy sandstone, a lower dark grey unit and an upper unit dominated by light grey and redbrown colours. The sedimentary structures and grain sizes do not show any marked changes and the main mechanisms of transport and deposition seem to have been rather uniform. The whole succession is thus considered to represent an association of genetically related facies.

The basal part of the association consists of muddy sandstone (facies 1 ; only $1.2 \mathrm{~m}$ exposed). It is followed with a sharp boundary by a unit dominated by dark grey mudstone with clay-ironstone layers (facies 2), $37.7 \mathrm{~m}$ thick, with numerous intercalations of thin siltstone and sandstone beds (facies 3). This unit is overlain with a sharp contact by a variegated mudstone unit, $14.9 \mathrm{~m}$ thick, (facies 4), which gradually gives way to a succession of calcareous mudstones and siltstones (facies 5); $15.9 \mathrm{~m}$ of this last unit was exposed in the 1970s.

The succession is interpreted to reflect changes in relative sea level in an area with uniform subsidence and relatively constant sediment influx. Thus, facies 1 represents slow deposition in a well-aerated shallow shelf sea. The muddy sand was originally deposited as alternating thin layers of mud and thicker layers of sand which were thoroughly mixed by bioturbation in the offshore transition to lower shoreface zone close to wave-base. The sharp boundary to the overlying mudstones of facies 2 is interpreted as a ravinement surface caused by combined drowning and transgressive erosion when coarser clastic material was trapped in estuaries and other inshore environments.

The main part of the succession represented by mudstone with coarser-grained intercalations (facies 2 and 3 ) was deposited in deeper offshore areas with periodic influxes of silt and sand from storm-generated suspension clouds. Most of the silt and sand beds were thoroughly bioturbated and their identity as storm deposits became less obvious. The unit shows an upwards decrease in the density and diversity of body fossils culminating at the almost barren $35 \mathrm{~m}$ level (Fig. 3). The top $4 \mathrm{~m}$ of the unit are again rich in body fossils. This trend is interpreted to have resulted from transgression and increasing water depth associated with a decrease in oxygenation followed by a regression combined with increasing oxygenation at the sea floor.

The variegated mudstones of facies 4 and 5 overlie the dark grey mudstone with a sharp contact $(38.9 \mathrm{~m}$ in Fig. 3) and are somewhat difficult to interpret environmentally. They have the finest grain size of the whole succession indicating very low energy conditions during deposition. The red colour and the occurrence of wrinkle marks or Kinneya ripples suggest well-oxygenated, very shallow water conditions. The sediments were possibly derived from erosion of finegrained red beds of Triassic age exposed in a nearby source area. The upwards increase in storm siltstones and sandstones suggests coastal progradation, whereas the scarcity of body and trace fossils suggests a marginal marine or high stress environment. The generally fine grain size points to deposition in a sheltered, somewhat enclosed area. The variegated mudstones with storm siltstones and sandstones of facies 4 and 5 thus seem to have been rapidly deposited in a very shallow marine, restricted environment under the influence of storms.

\section{Sequence stratigraphy}

The Döshult Member can be divided into six or seven coarsening-upwards units, about 2-8 m thick, with sharp upper boundaries (Fig. 3). They are typical examples of distal parasequences (Van Wagoner et al. 1990). Thin fining-upwards units, $10-20 \mathrm{~cm}$ thick, are not assigned any sequence stratigraphic significance but are interpreted as bioturbated storm siltstones and sand- 
stones. The parasequences stack into a parasequence set which shows a subtle overall fining-upwards trend accompanied by a distinct decrease in density and diversity of body and trace fossils (0-25 $\mathrm{m}$ in Fig. 3). The trend is interpreted as an overall backstepping stacking pattern which culminates in the poorly fossiliferous interval between $25 \mathrm{~m}$ and $35 \mathrm{~m}$ in the upper part of the Döshult Member (Fig. 3). A few thin conglomerates rich in body and trace fossils occur between $35 \mathrm{~m}$ and $38.9 \mathrm{~m}$.

The dark mudstones of the Döshult Member (facies 2) are overlain by the Pankarp Member with a sharp conglomeratic boundary at $38.9 \mathrm{~m}$. This unit comprises about 30 m of variegated, and red-brown, almost unfossiliferous mudstones which contain an upwards increasing number of thin storm siltstones and sandstones.

The slowly deposited fully marine muddy sandstones at the base of the section are interpreted to belong to the lower part of the transgressive systems tract. They are capped by a sharp erosional drowning or ravinement surface formed by transgressive marine erosion (TSE in Fig. 3). The overlying dark mudstones form the upper part of the transgressive systems tract (TST in Fig. 3). Lowstand deposits cannot be recognised and were probably not deposited in the area. The transgressive marine erosion surface corresponds to the lithostratigraphic boundary between units F-Ia and F-Ib (both F-I member) of the Fjerritslev Formation but is slightly younger than in most of the Danish Basin. The age of the erosion surface is close to the semicostatum-turneri Chronozone boundary.

A distinct maximum flooding surface cannot be identified on the basis of the available data but a maximum flooding zone is interpreted to occur at about $34 \mathrm{~m}$ (MFS in Fig. 3). The upper part, from $34 \mathrm{~m}$ to the top of the section may represent a simple highstand systems tract. The siderite pebble conglomerate at $38.9 \mathrm{~m}$ is not easy to interpret in terms of sequence stratigraphy. It occurs at a marked facies change from dark fossiliferous mudstones (facies 2) to variegated and redbrown almost non-fossiliferous mudstones (facies 4, 5). This change seems to represent a significant environmental change associated with a marked seawards shift in facies and it is possible that it represents a distal sequence boundary. If this is the case then the highstand systems tract of the underlying sequence is a maximum of $5 \mathrm{~m}$ thick and consists of dark, uniform mudstones at the top of the Döshult Member (34-38.9 m in Fig. 3). This interpretation is tentatively preferred here and the exposed Döshult Member thus includes a lower transgressive systems tract (TST), a transgres- sive surface of erosion (TSE), a thick upper transgressive systems tract (TST), a maximum flooding surface or zone (MFS) and a thin highstand systems tract (HST) topped by a distal sequence boundary (SB; Fig. 3). The overlying Pankarp Member probably represents poorly differentiated transgressive and highstand systems tracts.

The fossiliferous siderite pebble conglomerate at the Döshult-Pankarp Member boundary may be interpreted as reworked hiatus concretions formed when sediment supply to the basin was shut off during maximum flooding (Hesselbo \& Palmer 1992). This interpretation is, however, considered unlikely due to the marked facies change, the seawards shift in facies and the associated inferred major drop in water depth across the boundary.

Correlation to the contemporaneous Sose Bugt Member (Rønne Formation) on Bornholm in the Baltic Sea is hampered by the paralic, poorly fossiliferous nature of that unit (Surlyk et al. 1995). Dating of the Gantofta succession is based on ammonites, ostracodes and foraminifera, whereas the Sose Bugt Member is dated on the basis of pollen in the lower part and a few dinoflagellates in the upper part. A major sequence boundary is situated close to the Hettangian-Sinemurian boundary in the Sose Bugt section. This correlates well with a sequence boundary at the base of the Döshult Member in Skåne, below the Gantofta section (Surlyk et al. 1995). Two minor sequence boundaries are identified in the Sose Bugt section in the Lower Sinemurian and in the middle Upper Sinemurian, respectively. The lower sequence boundary occurs at a level roughly corresponding to the top of the muddy sandstone (facies 1 ) at the base of the Gantofta section (1.2 $\mathrm{m}$ in Fig. 3), whereas the upper one may correlate with the interpreted sequence boundary at the sharp break between dark mudstones (facies 2) and variegated mudstones (facies 4) at Gantofta (Döshult Member - Pankarp Member boundary; $38.9 \mathrm{~m}$ in Fig. 3). This correlation may corroborate the interpretation of the erosional boundary between the Döshult and Pankarp Members as representing the distal expression of a sequence boundary. It is remarkable that highstand systems tract deposits are almost absent in the Sinemurian Sose Bugt section which mainly consists of transgressive systems tract deposits. This is thought to be typical of the more proximal, basin margin areas (Surlyk et al. 1995) and may also account for the thinly-developed highstand deposits at Gantofta which occupied an intermediate basinal position between the paralic setting of the Sose Bugt Member and the offshore Danish Basin. Higher parts of the Pankarp Member are known from boreholes situated close to the Gantofta quarry. The red-brown, var- 
Fig. 4. Relative sea-level curve constructed for the Gantofta succession compared with the Jurassic sea-level curves of Haq et al. (1988) and Hesselbo \& Jenkyns (1998); the time scale is after Gradstein et al. (1994). An ammonite from the basal muddy sandstone at Gantofta suggests a mid-semicostatum Chronozone age for this level. The level of the obtusum Chronozone is well located and the lower part of the succession has a general Early Sinemurian age. The age of the postobtusum Chronozone beds is not wellknown but ostracode data suggest a Late Sinemurian age (Sivhed 1980).

MFS, maximum flooding surface; SB, sequence boundary.

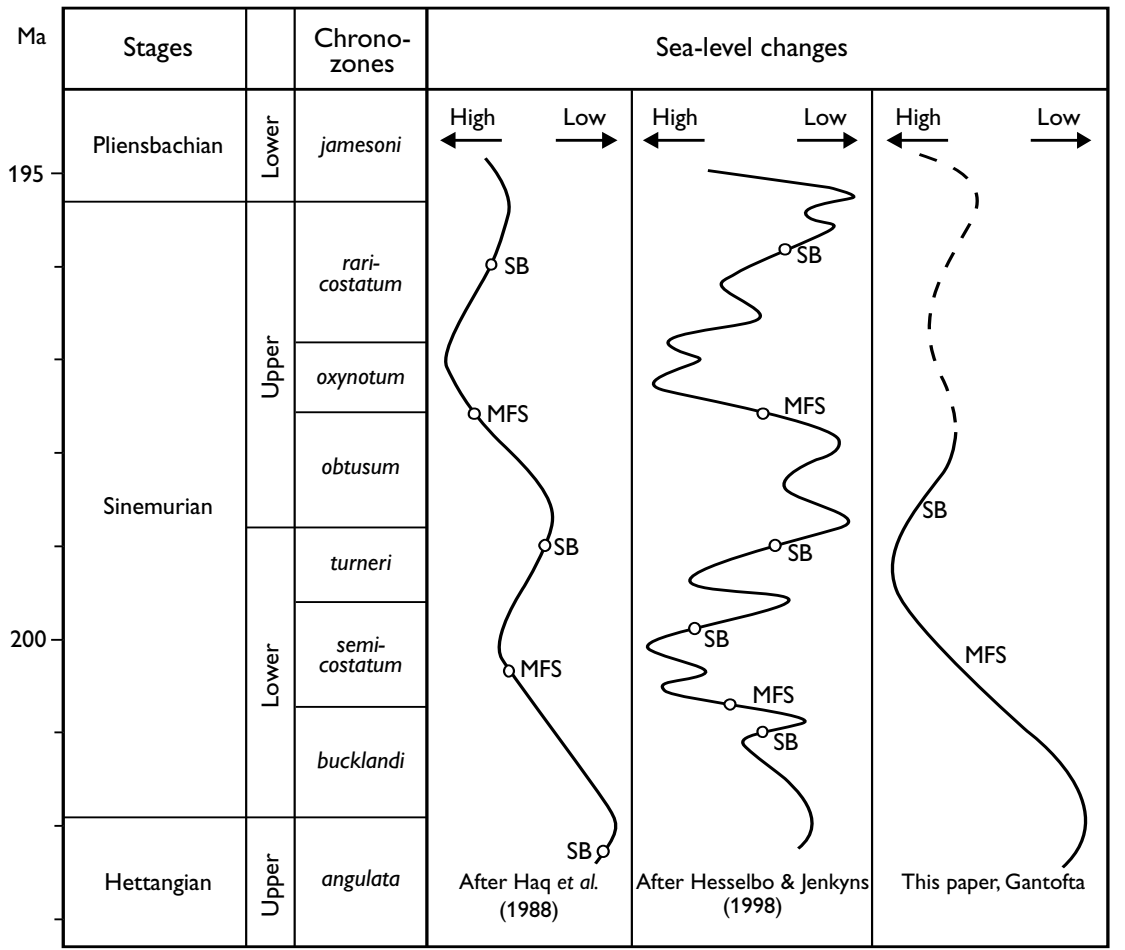

iegated and light grey mudstones of facies 4 and 5 are overlain by $10-17 \mathrm{~m}$ of bluish-grey mudstone. This is followed by about $5 \mathrm{~m}$ of sand with an allochthonous coal seam, $5-15 \mathrm{~cm}$ thick, representing a marked regression (Sivhed 1980). The sand is overlain by about 15 $\mathrm{m}$ of red-brown or bluish-grey mudstone. The Pankarp Member spans the Upper Sinemurian oxynotum and most of the raricostatum Chronozones. The nature of the lower boundary of the sand bed is not known and a sequence stratigraphic interpretation cannot be undertaken on the basis of the available data.

A relative sea-level curve constructed on the basis of the sedimentary evolution as interpreted here is shown on Figure 4. It is compared with the Jurassic eustatic sea-level curves of Haq et al. (1988) and Hesselbo \& Jenkyns (1998). The overall trends of the curves are remarkably similar, but the exact ages of the main highs and lows differ somewhat. The Haq et al. (1988) and Hesselbo \& Jenkyns (1998) curves show the highest degree of similarity although the latter is more detailed and shows more candidate sequence boundaries and maximum flooding surfaces. The two curves show major sequence boundaries in the uppermost Hettangian, uppermost Lower Sinemurian and uppermost Sinemurian, and maximum flooding surfaces in the middle Lower Sinemurian and middle Upper Sinemurian.

The Gantofta curve is simpler due to a combination of uniform facies development and lower biostrati- graphical resolution. It differs from the curve of Hesselbo \& Jenkyns (1998) in that they place the main Sinemurian sequence boundary at the base or immediately below the base of the obtusum Chronozone whereas it occurs within this chronozone at Gantofta. The mismatch between the Gantofta curve and the two other curves may be due to the basin marginal position and the lack of lowstand deposits at Gantofta. The low biostratigraphic resolution prevents identification of possible hiatuses in the mudstone-dominated succession. The eustatic signal may thus be overprinted by tectonism in the Fennoscandian Border Zone, by higher sediment input during transgression and condensation and bypass during regression. Hallam (1988) did not give any detailed zonal data for his transgressive and regressive events and his curve is thus difficult to compare with the other curves.

\section{Conclusions}

Until recently, a Lower Jurassic, Sinemurian marine succession, $70 \mathrm{~m}$ thick, was exposed at the Gantofta locality in north-western Skåne, southern Sweden. Gantofta represents the only place where it has been possible to study exposed strata of the same facies as the deeplyburied contemporaneous Fjerritslev Formation of the Danish Basin. The succession comprises the upper part 
of the Döshult Member and the lower part of the Pankarp Member, both belonging to the Sinemurian-Aalenian Rya Formation. The basal $1.2 \mathrm{~m}$ of the Gantofta section exposed the uppermost levels of the sand-dominated Lower Sinemurian part of the lower Döshult Member. This overall transgressive, fluvial and lacustrine to shallow marine succession is known from temporary exposures at nearby Örby where it is $32 \mathrm{~m}$ thick (Erlström et al. 1999).

Five genetically related facies are recognised. The lower half of the Gantofta section, representing the upper Döshult Member, is composed of three facies (1-3). The lowermost $1.2 \mathrm{~m}$ consists of Lower Sinemurian bioturbated, richly fossiliferous muddy sandstones (facies 1), interpreted as having been deposited relatively slowly in an offshore to transition zone environment. They are followed with a sharp contact by Lower - lower Upper Sinemurian, dark grey, bioturbated, fossiliferous mudstones (facies 2) with intercalations of siltstones and sandstones (facies 3). The mudstones represent slow, fair-weather deposition below wave base under offshore shelf conditions interrupted by deposition of thin silts and sands from storm-generated suspension clouds. The general low sedimentation rate and the distal, thin nature of the storm deposits is reflected by the pervasive bioturbation and mixing of both facies.

The succeeding Upper Sinemurian succession, referred to the lower Pankarp Member, comprises marginal marine, variegated mudstones and red-brown calcareous mudstones (facies 4, 5) with an upwards increasing number of storm siltstones and sandstones reflecting general shallowing and progradation of the coastline associated with restriction of the marine circulation. A fossiliferous siderite pebble comglomerate occurs at the boundary between the Döshult and Pankarp Members.

The succession encompasses the greater part of two, relatively simple depositional sequences. The basal muddy sandstone is interpreted as belonging to the lower transgressive systems tract of the lower sequence. It is topped by a ravinement surface formed by transgressive marine erosion overlain by a backstepping parasequence set representing the upper transgressive systems tract. A maximum flooding zone is identified close to the top of the dark Döshult Member mudstones. It is overlain by a thinly developed highstand systems tract topped by an erosion surface marked by the siderite pebble conglomerate. The erosion surface is tentatively interpreted as a distal sequence boundary and the overlying variegated and red-brown Pankarp Member mudstones belong to the poorly differentiated transgressive and highstand systems tracts of the second sequence. Comparison with the sequence stratigraphy of the contemporaneous Sose Bugt Member (Rønne Formation) of Bornholm lends some credence to this interpretation.

The Gantofta succession records an Early Sinemurian sea-level rise, a mid-Sinemurian highstand, an early Late Sinemurian sea-level fall followed by a Late Sinemurian minor rise and subsequent major fall. Data from nearby boreholes indicate an end Sinemurian Early Pliensbachian major rise. The sea-level curve constructed on the basis of the Gantofta section is compared with the sea-level curves of Haq et al. (1988) and Hesselbo \& Jenkyns (1998) in Figure 4. It is remarkable that the three curves show similar overall trends but the sequence boundaries and maximum flooding surfaces are delayed in the Gantofta curve compared to the two other curves. This may reflect the basin marginal position of the Gantofta section in the Fennoscandian Border Zone with higher sedimentation rates during sea-level rise and condensation or bypass during fall. Furthermore, the Gantofta curve is much simpler than the Hesselbo \& Jenkyns (1998) curve. This is probably a direct result of the poor biostratigraphic resolution of the Gantofta section and the implicit difficulty in identifying hiatuses in the mudstone-dominated succession.

\section{Acknowledgements}

We thank Ulf Sivhed for useful comments, Lars B. Clemmensen for critically reading an early manuscript version and referees Stephen P. Hesselbo and Gunver K. Pedersen for constructive criticism. The study was supported by the Carlsberg Foundation and the Danish Natural Science Research Council.

\section{References}

Ahlberg, A., Sivhed, U. \& Erlström, M. 2003: The Jurassic of Skåne, southern Sweden. In: Ineson, J.R. \& Surlyk, F. (eds): The Jurassic of Denmark and Greenland. Geological Survey of Denmark and Greenland Bulletin 1, 527-541 (this volume).

Bölau, E. 1959: Der Südwest- und Südostrand des Baltischen Schildes (Schonen und Ostbaltikum). Geologiska Föreningens i Stockholm Förhandlingar 81, 167-230.

Bölau, E. 1973: Pankarpslager (lias beta). Stratigrafisk definition och facies. Geologiska Föreningens i Stockholm Förhandlingar 95, 268-272.

Erlström, M., Sivhed, U. \& Surlyk, F. 1999: A backstepping fluviatile-paralic-marine succession, Sinemurian, Lower Jurassic, 
Skåne, southern Sweden. Bulletin of the Geological Society of Denmark 46, 1-12.

Frandsen, N. 1977: Aflejringsmiljøer i Skånes Rhæt-Lias, 95 pp. Unpublished cand. scient. thesis, Københavns Universitet, Danmark.

Gradstein, F.M., Agterberg, F.P., Ogg, J.G., Hardenbol, J., Van Veen, P., Thierry, J. \& Huang, Z. 1994: A Mesozoic time scale. Journal of Geophysical Research 99, 24051-24074.

Gravesen, P., Rolle, F. \& Surlyk, F. 1982: Lithostratigraphy and sedimentary evolution of the Triassic, Jurassic and Lower Cretaceous of Bornholm, Denmark. Danmarks Geologiske Undersøgelse Serie B 7, 51 pp.

Hallam, A. 1988: A reevaluation of Jurassic eustasy in the light of new data and the revised Exxon curve. In: Wilgus, C.K. et al. (eds): Sea-level changes - an integrated approach. Society of Economic Paleontologists and Mineralogists Special Publication 42, 261-273.

Häntzschel, W. \& Reineck, H.E. 1968: Fazies-Untersuchungen im Hettangium von Helmstedt (Niedersachsen). Mitteilungen aus dem Geologischen Staatsinstitut in Hamburg 37, 5-39.

Haq, B.U., Hardenbol, J. \& Vail, P.R. 1988: Mesozoic and Cenozoic chronostratigraphy and cycles of sea-level change. In: Wilgus, C.K. et al. (eds): Sea-level changes - an integrated approach. Society of Economic Paleontologists and Mineralogists Special Publication 42, 71-108.

Hesselbo, S.P. \& Jenkyns, H.C. 1998: British Lower Jurassic sequence stratigraphy. In: de Graciansky, P.-C. et al. (eds): Mesozoic and Cenozoic sequence stratigraphy of European basins. SEPM (Society for Sedimentary Geology) Special Publication 60, 561-581.

Hesselbo, S.P. \& Palmer, T.J. 1992: Reworked early diagenetic concretions and the bioerosional origin of a regional discontinuity within British Jurassic marine mudstones. Sedimentology 39, 1045-1065.

Lund, J.J. 1977: Rhaetic to Lower Liassic palynology of the onshore south-eastern North Sea Basin. Danmarks Geologiske Undersøgelse II. Række 109, 129 pp.

Michelsen, O. 1975: Lower Jurassic biostratigraphy and ostracods of the Danish Embayment. Danmarks Geologiske Undersøgelse II. Række 104, 287 pp.

Michelsen, O. 1978: Stratigraphy and distribution of Jurassic deposits of the Norwegian-Danish Basin. Danmarks Geologiske Undersøgelse Serie B 2, 28 pp.

Michelsen, O. 1989: Log-sequence analysis and environmental aspects of the Lower Jurassic Fjerritslev Formation in the Danish Subbasin. Danmarks Geologiske Undersøgelse Serie A 25, 23 pp.

Michelsen, O., Nielsen, L.H., Johannessen, P.N., Andsbjerg, J. \& Surlyk, F. 2003: Jurassic lithostratigraphy and stratigraphic development onshore and offshore Denmark. In: Ineson, J.R. \& Surlyk, F. (eds): The Jurassic of Denmark and Greenland. Geological Survey of Denmark and Greenland Bulletin 1, 147-216 (this volume).

Nielsen, L.H. 2003: Late Triassic - Jurassic development of the Danish Basin and the Fennoscandian Border Zone, southern Scandinavia. In: Ineson, J.R. \& Surlyk, F. (eds): The Jurassic of Denmark and Greenland. Geological Survey of Denmark and Greenland Bulletin 1, 459-526 (this volume)
Norling, E. 1972: Jurassic stratigraphy and foraminifera of western Scania, southern Sweden. Sveriges Geologiska Undersökning Serie Ca 47, 120 pp.

Norling, E. 1981: Upper Jurassic and Lower Cretaceous geology of Sweden. Geologiska Föreningens i Stockholm Förhandlingar 103, 253-269.

Norling, E. \& Bergström, J. 1987: Mesozoic and Cenozoic tectonic evolution of Scania, southern Sweden. In: Ziegler, P.A. (ed.): Compressional intra-plate deformations in the Alpine Foreland. Tectonophysics 137, 7-19.

Norling, E., Ahlberg, A., Erlström, M. \& Sivhed, U. 1983: Guide to the Upper Triassic and Jurassic geology of Sweden. Sveriges Geologiska Undersökning Serie Ca 82, 71 pp.

Pedersen, G.K. 1985: Thin, fine-grained storm layers in a muddy shelf sequence: an example from the Lower Jurassic in the Stenlille 1 well, Denmark. Journal of the Geological Society (London) 142, 357-374.

Pedersen, G.K. 1986: Changes in the bivalve assemblage of an Early Jurassic mudstone sequence (the Fjerritslev Formation in the Gassum 1 well, Denmark). Palaeogeography, Palaeoclimatology, Palaeoecology 53, 139-168.

Pieńkowski, G. 1991a: Liassic sedimentation in Scania, southern Sweden: Hettangian-Sinemurian of the Helsingborg area. Facies 24, 39-86.

Pieńkowski, G. 1991b: Eustatically-controlled sedimentation in the Hettangian-Sinemurian (Early Jurassic) of Poland and Sweden. Sedimentology 38, 503-518.

Reineck, H.E. \& Singh, I.B. 1980: Depositional sedimentary environments, 549 pp. Berlin, Heidelberg, New York: Springer Verlag.

Reyment, R.A. 1969a: Upper Sinemurian (Lias) at Gantofta, Skåne. Geologiska Föreningens i Stockholm Förhandlingar 91, 208-216.

Reyment, R.A. 1969b: A note on Promicroceras. Geologiska Föreningens i Stockholm Förhandlingar 91, 440-442.

Rolle, F., Koch, J.-O., Frandsen, N. \& Surlyk, F. 1979: Jurassic environments in the Fenno-Scandian Border Zone. Symposium on 'Sedimentation jurassique W. européen'. Association Sedimentologie Francais Publication Speciale 1, 15-31.

Sellwood, B.W. 1971: The genesis of some sideritic beds in the Yorkshire Lias. Journal of Sedimentary Petrology 41, 854-858.

Sellwood, B.W. 1972: Tidal-flat sedimentation in the Lower Jurassic of Bornholm, Denmark. Palaeogeography, Palaeoclimatology, Palaeoecology 11, 93-106.

Sivhed, U. 1977: A Lower Jurassic ostracode fauna in the Gantofta Brick Pit, Skåne, southern Sweden. Sveriges Geologiska Undersökning Serie C 730, 31 pp.

Sivhed, U. 1980: Lower Jurassic ostracodes and stratigraphy of western Skåne, southern Sweden. Sveriges Geologiska Undersökning Serie Ca 50, 84 pp.

Sivhed, U. 1981: Stratigraphy of the Gantofta-Katslösa area in Scania, Sweden. Geologiska Föreningens i Stockholm Förhandlingar 103, 249-252.

Sivhed, U. 1984: Litho- and biostratigraphy of the Upper Triassic - Middle Jurassic in Scania, southern Sweden. Sveriges Geologiska Undersökning Serie C 806, 31 pp.

Surlyk, F. \& Noe-Nygaard, N. 1986: Hummocky cross-stratification from the Lower Jurassic Hasle Formation of Bornholm, Denmark. Sedimentary Geology 46, 259-273. 
Surlyk, F., Arndorff, L., Hamann, N.-E., Hamberg, L., Johannessen, P.N., Koppelhus, E.B., Nielsen, L.H., Noe-Nygaard, N., Pedersen, G.K. \& Petersen, H.I. 1995: High-resolution sequence stratigraphy of a Hettangian-Sinemurian paralic succession, Bornholm, Denmark. Sedimentology 42, 323-354.

Troedsson, G. 1951: On the Höganäs Series of Sweden (Rhaeto-
Lias). Lunds Universitets Årsskrift Ny Följd 2 47(1), 269 pp. Van Wagoner, J.C., Mitchum, R.M., Campion, K.M. \& Rahmanian, V.D. 1990: Siliciclastic sequence stratigraphy in well logs, cores, and outcrops: concepts for high-resolution correlation of time and facies. American Association of Petroleum Geologists Methods in Exploration Series 7, 55 pp.

Manuscript received 23 May 1997; revision accepted 13 October 1999. 